\title{
Factors Contributing to Repayment Behavior of Micro Loans in Agricultural Bank of Meshkinshahr
}

\author{
Ahmad Fatollahi \\ Dep. of Agriculture Economics, University of Tabriz \\ 29 Bahman Boulevard, Tabriz, Iran \\ E-mail: ahmad_f27@yahoo.com \\ Ebrahim Samani (Corresponding author) \\ Dep. of Language and Humanities, Universiti Putra Malaysia \\ 43400 Serdang, Selangor, Malaysia \\ E-mail: ibrahim.samani@gmail.com
}

Received: September 22, 2014 Accepted: October 17, $2014 \quad$ Published: March 30, 2014

doi:10.5296/ifb.v2i1.7748 URL: http://dx.doi.org/10.5296/ifb.v2i1.7748

\begin{abstract}
The purpose of this study was to identify factors influencing on repayment behavior of loans by farmers who received loans from rural branches of Agricultural Bank in Meshkinshahr. Data for this study was obtained from a sample of one- hundred- and -fifty farmers who defaulted in paying their loans to Agricultural Bank. Logistic regression through strata software was used to analyze data. According to the results, the variables of supervision, occupation, other credit received, and education were found to be significant predictors of repayment in Agricultural Bank of Meshginshahr. Findings of this study will give valuable insights to policy makers and planners in the bank in terms of awarding micro loans which can be used in credit policies of the bank.
\end{abstract}

Keywords: Logistic regression, Agricultural Bank of Iran, Micro loans, Repayment, Strata 


\section{Introduction}

In Iran, Agricultural Bank is one of the institutions who have played an influential role in allocating loans in rural communities of Iran. In other words, in terms of number and amount of loans, micro loans account for 95 percent of total loans and 50 percent of the loans that were paid in Agricultural Bank of Iran in 2013. As a result, applicants for micro loans constitute a significant portion of the bank's customers.

There are two main sources for financing these lending to small-scale farmers: increase in bank monetary resources and recovery of overdue awarded credits. Meanwhile, the specific approach of Agricultural Bank as a professional institution has resulted in less customer savings in comparison with other banks. Consequently, collection of overdue payments is the most important resource to finance future applications for loans (Koopahi, 2003). Unfortunately, Agricultural bank challenges a high rate of over due repayment and the percentage of default on loans is calculated around 20 percent. These non-payments have initiated major problems such as increased credit risk, waste of resources and time, increase in bank costs, and a blockage in the portion of the Bank's lending resources and disruption in the plans of the Bank (Hossein Sharifi, 2011). Thus, the Agricultural Bank as a provider of financial services to farmers is entirely dependent on repayment of loans to provide necessary credit. However, Due to the high incidence of default in Agricultural Bank of Meshkinshahr, this bank faces serious problems in its potential in allocating loans to farmers in rural areas. Accordingly, the main objective of this study was to investigate the factors affecting the repayment behavior of loans by farmers in Agricultural bank of Meshkinshahr.

\section{Review of the Literature}

There have been a large number of studies in the literature that have been carried out on the topic of loan default. Previous studies have presented some of the reasons for the issue of default that include but not limited to attitude of loan receivers, ineffective policies within credit institutions, losses from farm investments, application of loans in non-farm enterprises, and regarding loan as a share of national resources without a need to pay. Ewuola (1996) studied the characteristics of loan institution on repayment of loan in Nigeria. The results showed farmers who failed to repay had a middle age and low levels of education. In addition, loan supervision and high rates of interest on loans repayment had a positive effect on loan repayment.

Matin (1997) investigated the problems of farmers in repayment of the Agricultural loans according to Logit model. The results indicated that the level of education, credit history, non agricultural income and land under cultivation are important factors affecting the loan repayment. In another study carried out in Madagascar, Zeller (1998) investigated repayment of micro loans using Tobit model and showed that groups with a higher level of integrity had a better repayment.

In his study of the factors affecting repayment of micro loans in Ethiopia, Gebeyehu (2002) concluded that loan rate, loan size, form and period of loan payment, previous credit experience, training and education, business and economic activity experience are among the 
influential factors affecting loan repayment in that area. In addition, Gadquin (2004) analyzed the performance of small financial institutions on repayment of micro loans. Using Probit model, he identified the ways to improve the collection of loans and showed that improvement in the rate of repayment, non-financial services, dynamic incentives, reduction in the cost of loan allocation, farmer education, proper selection of borrowers who did not have any overdue repayment had a positive effect in the collection of repayment performance.

Adegbite (2009) examined factors affecting repayment of loans in Nigeria. The results indicated that the amount of the loan, delay in payment, distance between field of agriculture and bank, age, knowledge and experience in agriculture, natural damage and disease and pests had a significant effect on the repayment of loans. Rahji (2010) in his study, conducted on the banks of the South-West Nigeria, focused on identifying factors affecting the decision of banks to ration credits. He concluded that the size of farmers' field, their income in the previous year, the type of company, the net assets of the household, business level of agricultural family were among important factors in the probability of delinquency in loans by farmers.

Fikirte (2011) also investigated the factors affecting the repayment of micro loans in Addis Ababa. Analysis of data was conducted through Logit model A total of twelve explanatory variables were entered in the regression equation. According to the results, variables such as age, type of business, (Sub market, kiosk, knitting and sewing services, and agriculture), gender, business experience played a significant role on the performance of micro loans repayment.

In another study, Mahmud et al. (2012) analyzed the various factors affecting repayment in Kasoor area in the Punjab province of Pakistan. They concluded that inadequate loan supervision of bank employees, form of loan use, high interest rates, and changes in business and residence of the borrower, resulted in a delay in repayment of agricultural credit in the region. In their study designed to investigate factors enhancing loan repayment by potato growers in Ghana, Wongnaa and Awonyn-vitor (2013) found that factors like age, education, experience, supervision, and the income outside farm was influential in loan repayment. Additionally, gender and marital status had a negative effect on repayment

\section{Method}

This study examined the role of the factors influencing on loan repayment performance of the farmers who had delinquency in loan repayment received from Agricultural bank of Meshginshahr. Independent variables in this study included gender, education, occupation, source of income, distance to bank, savings, other credit received, explanation before getting a loan, supervision, loan interest rate, period of repayment, mode of repayment. Dependent variable was defined as whether farmers had delayed repayment of loan installments to the bank. Hence, if farmer had not any delayed repayment, value of dependent variable was zero and otherwise one. 


\subsection{Participants}

This study consisted of 150 respondents who were customers of Agricultural Bank branches in Meshkinshar, in Ardabil province. Respondents were both males $(n=115,76.7 \%)$ and females $(n=35,23.3 \%)$. They have an average age of 40.63 years of old. In terms of marital status, $5.3 \%$ of them $(\mathrm{n}=8)$ were single, 92.7 of them were married and 2 percent of them $(n=3)$ reported to be widow or widower. As it was expected, most of them $(n=90,60 \%)$ reported to work in agricultural, 6 percent of the $(n=9)$ was in business, and $34 \%$ of the respondents $(n=47)$ selected the other option as their main job. According to Table 1, Literacy level of respondents was generally low with illiterate farmers constituting $16 \%$, primary education $18 \%$, and secondary education $26 \%$ of the respondents whilst the percentage of respondents with tertiary degree was 39 percent and finally the average distance of farmers with the bank was about 13.11 kilometers.

Table 1. Demographic characteristics of the respondents in the study

\begin{tabular}{|c|c|c|c|}
\hline & $\mathrm{n}$ & $\%$ & mean \\
\hline \multicolumn{4}{|l|}{ Gender } \\
\hline male & 115 & 76.7 & \\
\hline female & 35 & 23.3 & \\
\hline Age & & & 40.63 \\
\hline \multicolumn{4}{|l|}{ Marital status } \\
\hline single & 8 & 5.3 & \\
\hline married & 139 & 92.7 & \\
\hline widow or widower & 3 & 2 & \\
\hline \multicolumn{4}{|l|}{ Job } \\
\hline agricultural & 90 & 60 & \\
\hline business & 9 & 6 & \\
\hline services & 47 & 34 & \\
\hline \multicolumn{4}{|l|}{ Education } \\
\hline illiterate & 24 & 16 & \\
\hline primary & 27 & 18 & \\
\hline secondary & 40 & 26 & \\
\hline tertiary & 59 & 39 & \\
\hline Distance to bank & & & 13.11 \\
\hline
\end{tabular}

The selection criteria were the loan recipients in Agricultural Bank of Meshkinshahr who had overdue repayments. They were selected based on convenience sampling. Participants were approached by the researcher when they wanted to repay some of their overdue loans and 


\section{Al Macrothink}

asked to answer the questionnaire. The researcher of the study explained the purpose of the study and any questions about the questionnaire, furthermore, he ensured respondents of their anonymity.

\subsection{Instrument}

In this study, data was collected using a questionnaire which was adapted from Mokhtar (2011) and Abafita (2003). This questionnaire was made of 8 sections and asked respondents on their demographic variables (Section 1), use of loan (Section 2), loan and repayment (Section 3), loan supervision (Section 4), occupation and revenue (Section 5and 6), education cost (Section 7), other information (Section 8).

\subsection{Data Analysis}

The purpose of this study was to investigate the factors predicting the non-repayment of micro loans using an appropriate theoretical model. Since repayment or non-repayment of micro loans as a dependent variable is a binary variable, the use of regression model appears as an appropriate model. Logistic regression requires the dependent variable divides into yes and no variables. In other words, they endorse the presence or absence of a condition. Statistical analysis was conducted using Strata 12. Strata is a friendly command-driven program and users can conduct statistical analysis through simple command structure or available dialog boxes.

\section{Results}

Table 2 Descriptive statistics of two groups of Loan recipients in Agricultural Bank of Meshkinshahr non-repayment group repayment group

\begin{tabular}{|c|c|c|c|c|}
\hline & \multicolumn{2}{|c|}{ Non-repayment Group } & \multicolumn{2}{|c|}{ Repayment Group } \\
\hline & $\mathrm{N}$ & $\%$ & $\mathrm{~N}$ & $\%$ \\
\hline \multicolumn{5}{|l|}{ Age } \\
\hline $30>$ & 19 & 17.9 & 8 & 18.2 \\
\hline $30-60$ & 66 & 62.3 & 29 & 65.9 \\
\hline $60<$ & 21 & 19.8 & 7 & 15.9 \\
\hline \multicolumn{5}{|l|}{ Gender } \\
\hline Male & 84 & 79.2 & 32 & 72.7 \\
\hline Female & 22 & 20.8 & 12 & 27.3 \\
\hline \multicolumn{5}{|l|}{ Job } \\
\hline Agricultural & 38 & 35.8 & 24 & 54.5 \\
\hline Non-agricultural & 68 & 64.2 & 20 & 45.5 \\
\hline \multicolumn{5}{|l|}{ Repayment Period } \\
\hline 6 months & 6 & 5.7 & 2 & 4.5 \\
\hline 1 year & 38 & 35.8 & 13 & 29.5 \\
\hline
\end{tabular}




\begin{tabular}{|c|l|l|l|l|}
\hline 2 year & 8 & 7.5 & 5 & 11.4 \\
\hline 3 year & 33 & 31.1 & 15 & 34.1 \\
\hline more & 21 & 19.8 & 9 & 20.5 \\
\hline Other credit received & & & & \\
\hline Received & 57 & 53.8 & 23 & 52.3 \\
\hline Not received & 49 & 46.2 & 21 & 47.7 \\
\hline Savings & & & & \\
\hline Yes & 78 & 73.6 & 39 & 88.6 \\
\hline No & 28 & 26.4 & 5 & 11.4 \\
\hline Distance to the Bank & & & & \\
\hline $30 \mathrm{~km}>$ & 96 & 90.6 & 40 & 90.9 \\
\hline $30-60 \mathrm{~km}$ & 9 & 8.5 & 4 & 9.1 \\
\hline $60 \mathrm{~km}<$ & 1 & 0.9 & 0 & 0 \\
\hline
\end{tabular}

According to Table 2, most of the loan recipients in NR group $(\mathrm{n}=66,62.3 \%)$ and $\mathrm{R}$ group $(n=29,65.9 \%)$ were between 30 to 60 years of age. In addition, the recipients of loans in both NR group ( $n=84,79.2 \%$ ) and $R$ group $(n=3272.7 \%$ ) were predominantly males. About 64.2 percent of respondents in NR group $(n=68)$ and $54.5(n=24)$ in $R$ group reported to be involved in agricultural job which was expected because the respondents of this study were farmers who visited Agricultural Bank. Repayment period of one year included most of the farmers in non-repayment group $(n=38,35.8 \%)$. However, for Repayment group, period of 3 years was most prevalent $(n=15,34.1 \%)$. In response to whether they had received loans from other banks, the number of respondents who answered yes in non-repayment group $(n=57$, $53.8 \%)$ were higher than loan recipients from other banks in $\mathrm{R}$ group $(\mathrm{n}=23,52.3 \%)$. Additionally, Farmers with saving in R group was slightly higher than farmers in NR group. Finally, according to the distance between their residential area and the bank, about 90.6 percent of farmer in NR group and 90.9 percent of farmers in R group selected the distance of less than 30 kilometers.

In this study, it was hypothesized that a series of factors like distance to bank, other credit received, loan interest rate, explanation, supervision, job, mode of repayment, period of repayment, source of income, savings, age, gender, and education would predict the non-repayment of allocated loans by Agricultural Bank. Direct logistic regression was performed to assess the impact of these factors on the likelihood that respondents would not have any overdue repayment. The model contained all of these 13 independent variables. As the Table 2 indicate the full model containing all predictors was statistically significant, $\chi(13$, $\mathrm{N}=149)=36.48, \mathrm{p}<.001$, indicating that the model was able to distinguish between respondents who reported and did not report overdue repayment 


\section{Ml Macrothink}

Table 3. Logistic regression analysis

\begin{tabular}{|l|c|c|c|c|c|}
\hline & S.E & $\mathrm{p}$ & \multicolumn{2}{|c|}{ Odds Ratio } & \multicolumn{2}{|c|}{$95.0 \%$ conf. Interval } \\
\hline Age & .12 & .12 & .98 & .58 & 1.0 \\
\hline gender & .13 & .09 & 1.77 & .33 & .36 \\
\hline education & .08 & .01 & .01 & 2.55 & 4.81 \\
\hline occupation & .00 & .05 & 2.7 & 2.59 & .86 \\
\hline source of income & .13 & .21 & .70 & .00 & 4.81 \\
\hline distance to bank & .19 & .18 & 1.01 & .91 & 1.67 \\
\hline savings & .13 & .08 & .27 & .01 & 1.30 \\
\hline other credit received & .04 & .00 & 1.07 & .00 & 1.70 \\
\hline explanation before getting a loan & .08 & .10 & .26 & .00 & 1.88 \\
\hline loan supervision & .07 & .01 & .32 & 16.04 & 4.28 \\
\hline loan interest rate & .22 & .12 & 1 & .03 & 1.50 \\
\hline period of repayment & .08 & .06 & 1.38 & .00 & 1.08 \\
\hline mode of repayment & 4.54 & .45 & .96 & .17 & 55.52 \\
\hline
\end{tabular}

According to Table 3, the results of the logistic regression analysis showed that the variables of supervision, job, number of loans from other banks, and education were statistically significant. This means that these four variables can be a good predictor of farmers' non-repayment. By contrast the variables of distance to bank, loan interest rate, explanation, repayment mode, repayment period, source of income, savings, age, sex were not significant. The odd ratio for loan supervision is 1.15 means that for a unit increase in supervision, likelihood that a farmer will pay the loan increases by 32 percent. Since it is hard to compare the odds ratio for one variable with the odds ratio for another variable when they are measured on different scales, the effect of a 1-standard-deviation change for the significant variables in this study was evaluated. The reason for using standard deviation as a basis for analysis is that when variables are on the same scale, the comparison makes more sense.

Table 4 Factor and percentage change in odds

\begin{tabular}{|l|c|c|c|c|c|}
\hline & $\mathrm{b}$ & $\mathrm{p}$ & Odds Ratio & $\mathrm{e}^{\wedge} \mathrm{b}$ Stdx & $\%$ StdX \\
\hline Age & -0.24 & .12 & .98 & .05 & -95 \\
\hline gender & 6.99 & .09 & 1.77 & 19.03 & 18 \\
\hline education & 4.08 & .01 & .01 & .22 & 92.4 \\
\hline occupation & -7.66 & .05 & 2.7 & .02 & -97.7 \\
\hline source of income & -2.86 & .21 & .70 & .24 & -76.1 \\
\hline distance to bank & 0.21 & .18 & 1.01 & 29.74 & 28.7 \\
\hline other credit received & -2.32 & .08 & .27 & .07 & -93.4 \\
\hline explanation before getting a loan & -4.11 & .00 & 1.07 & .13 & 87.2 \\
\hline
\end{tabular}




\section{Macrothink}

\begin{tabular}{|l|c|c|c|c|c|}
\hline loan supervision & 11.33 & .01 & .32 & .03 & -96.2 \\
\hline loan interest rate & -1.51 & .12 & 1 & .33 & -67.3 \\
\hline period of repayment & -3.05 & .06 & 1.38 & .03 & -97.3 \\
\hline mode of repayment & 1.12 & .45 & .96 & 1.76 & 75.8 \\
\hline
\end{tabular}

Note. $\mathrm{b}=$ raw coefficient;

$\% \mathrm{StdX}=$ percent change in odds for SD increase in $\mathrm{X}$;

$\mathrm{e}^{\wedge} \mathrm{b}$ Stdx $=$ change in odds for SD increase in $\mathrm{X}$.

According to Table 4, having a 1-standard-deviation-higher percentage of farmers who reported having a job decreases the odds of non-repayment by $97.7 \%$. In addition, the odd ratio for a 1-standard-deviation change in education was .01 meaning that a one-standard-deviation increase in education level of loan receivers will increase the odd of default on repayment by $92.4 \%$. Meanwhile, application of loan supervision 1 standard deviation more often reduces the odds of non-repayment by $96.2 \%$. Finally, an increase of about 1-standard-deviation in the variable of other credit received helps to reduce the odds of non-repayment by $87.2 \%$.

\section{Discussion}

This study focused on loan repayment problem examining the factors that were hypothesized to be effective in non-repayment of loans in Agricultural Bank of Meshkinshahr. The prediction value of some exploratory variables was studied including distance to bank, other credit received, loan interest rate, explanation, supervision, job, and mode of repayment, period of repayment, source of income, savings, age, gender, and education. Obtained data was analyzed by Strata statistical software. According to the results of logistic regression analysis, loan supervision was found to be a good predictor of non -repayment which is in consistent with previous studies in that applying a good loan supervision by the bank before, during and after allocating loans will help to the repayment of loans (Ewuola, 1996; Mehmood et al., 2012). According to Wilson (1983), monitoring and supervision is a multi-faceted set of activities with one prime objective; that of improving our knowledge about what is going on" (p. 200). In addition, absence of loan supervision may result in large-scale use of these agricultural loans in non-productive sectors. As one of analyzed variables, the occupation of recipients of loans was also found to be a significant predictor. This variable was significant at $p<.05$. It significantly accounted for variances in the dependent variable of non-repayment. According to previous studies, repayment of loan is dependent on the type of occupation (Ewuola, 1996; Gebeyehu, 2002). It appears that involvement in non-farm activities will help farmers to repay their loans on time. It is believed that involvement in non-farm occupation are not usually associated with risks that are inherent in agriculture like pests and bad weather and provide farmers with sustainable source of income that enable them to honor repayment obligations. Natural hazards is considered as one of the greatest impediments to loan repayment. According to the result of 
the analysis, the variable of number of loans from other banks was also found to be a significant predictor of non-repayment $(\mathrm{p}=.00)$. It appears that farmers who receive credit from other banks may encounter with difficulty in the repayment of the loans.

The other important factor that found to predict the non- repayment of loans by the participants in this study was education which is do not support the findings of previous studies in that educated farmers are more likely to repay their loans (Abafita, 2003; Bhatt \& Tang, 2002). According to Bhatt and Tang (2002), educated borrower is able to manage the business well, comprehend information, keep business records and conduct a cash flow analysis.

\section{Conclusions and Recommendations}

Results of this study tend to suggest that careful management of these four variables could vastly improve agricultural loan repayment by farmers. However, results of this study need to be interpreted with caution because most of the respondents in this study were illiterate or of primary or secondary education and were likely to misunderstand the questions or provide biased answer even with the help of the researcher. In regards to the importance of micro loans in providing rural residents with employment, it is suggested that Agricultural Bank award loans designed to encourage home -based jobs and non-agricultural professions which will promote non-agricultural professions in villages and ultimately increase the welfare of the villagers.

However, the problem of delinquency in paying loans needs an immediate response. If the problem of defaulters continues to exist, it will hamper further programs by credit institutions like Agricultural Bank in financing small scale farm loans. There is a need to change the belief among farmers that loans especially from public institution is not free credits and on time repayment of these facilities will help to the provision of them to other applicants. Due to recent increase in initiating legal action against defaulters in Iran, any research on the issue will give significant insights on the effectiveness of this new approach in recovery of overdue repayments in banks of Iran.

\section{References}

Abafita, J. (2003). Microfinance and loan repayment performance: A case study of the Oromia credit and savings share company (OCSSCO) in Kuyu. Master's thesis, Addis Ababa University.

Abraham, G. (2002). Loan repayment and its determinants in small scale enterprises financing in Ethiopia: A case of private borrowers around Zeway Area. Doctoral dissertation, Master Thesis. Addis Ababa University, Ethiopia.

Adams, D. W., \& Graham, D. H. (1981). A critique of traditional agricultural credit projects and policies. Journal of Development Economics, 8(3), 347-366. http://dx.doi.org/10.1016/0304-3878(81)90021-3

Addisu, M. (2006). Micro-finance repayment problems in the informal sector in Addis Ababa. Ethiopian Journal of Business \& Development, 1(2), 29-50. 
Adegbite, D. A. (2009). Repayment performance of beneficiaries of Ogun State Agricultural Andmulti-purpose Credit Agency (Osamca) In Ogun State, Nigeria (2004-2007). American-Eurasian Journal of Sustainable Agriculture, 3(1), 117-125.

Bhatt, N., \& Tang, S. Y. (2001). Delivering microfinance in developing countries: Controversies and policy perspectives. Policy Studies Journal, 29(2), 319-333. http://dx.doi.org/10.1111/j.1541-0072.2001.tb02095.x

Ewuola, S. W. (1996). Effects of institutional and borrower characteristics on loan recovery: A study of Ondo State agricultural credit corporation. Agrosearch, 1(2), 58-67.

Fikirte, K. (2011). Determinants of loan repayment performance: A case study in the Addis Credit and Sharing Institution. Addis Abba, Ethiopi: M.SC. Thesis. Wageningen university the Netherlandy.

Godquin, M. (2004). Microfinance repayment performance in Bangladesh: How to improve the allocation of loans by MFIs. World Development, 32(11), 1909-1926. http://dx.doi.org/10.1016/j.worlddev.2004.05.011

IFAD. (2003). The Rural development potential of IFAD's credit projects. Retrieved from http://www.IFAD. org

Matin, I. (1997). Repayment performance of Grameen bank borrowers: The unzipped state. Savings and Development, 45, 1-473.

Mehmood, Y., Anjum, M. B., \& Ahmad, M. (2012). Factors affecting delay in repayments of agricaltural credit: A case study of district Kadur of panjab province. World Applied Sciences Journal, 17(4), 447-452.

Mokhtar, S. H. (2011). Microfinance performance in Malaysia. Doctoral dissertation. Lincoln University.

Njoku, J. E., \& Odii, M. A. C. A. (1991). Determinants of loan repayment under the special emergency loan scheme (SEALS) in Nigeria: A case study of Imo state. African Review of Money Finance and Banking, 39-52.

Oladeebo, O. E. (2003). Socio-Economic Factors. Influencing Loan Repayment Among Small Scale Farmers in Ogbomoso Agricultural Zone of Oyo State, Nigeria. Full Professional Diploma Project (unpublished), Department of Management Science, Ladoke Akintola University of Technology, Ogbomoso.

Rahji, M. (2010). Determinants of agricultural credit rationing by commercial Bank in south-west Nigeria. Journal of Finance International Research and Economic, 37, Retrieved from http://www.eurojournals.com/Htm

Saleem, A., Alijan, F., \& Khattak, R. M., \& Quraishi, M. I. (2006). Impact of farm and farmers characteristics on repayment of agricultural credit: A case study of Khyher pokhtoonkhawa. Ahasgn Journal of Social Sciences, 4(1).

Vigan, L. (1993). A credid-scoring model for development bank: An African case study. 
Savings and Development, 17(4), 441-479.

Wilson, F. A. (1983). Monitoring small farm credit. Agricultural Administration, 14(4), 191-202.

Wongnaa, C. A. \& Awonyn-vitor, D. (2013). Factors affecting loan repayment performance among Yam farmers in the Sene district, Ghana. Agricultural Online Papers in Economics, 5(2).

Zeller, M. (1996). Determinants of repayment performance in credit G groups: The role of program design intra-group risk pooling, and social cohesion in Madagascar. Economic Development and Cultural Change, 43(3), 599-620.

\section{Copyright Disclaimer}

Copyright for this article is retained by the author(s), with first publication rights granted to the journal. This is an open-access article distributed under the terms and conditions of the Creative Commons Attribution license (http://creativecommons.org/licenses/by/3.0/). 